\title{
Tracheal compression: a late complication of plombage
}

\author{
Zoe Elizabeth Barber, ${ }^{1}$ Thomas David Dobbs, ${ }^{2}$ Mitra Shahidi ${ }^{1}$ \\ ${ }^{1}$ Department of Respiratory Medicine, Stoke Mandeville Hospital, Aylesbury, UK \\ ${ }^{2}$ Department of Acute General Medicine, John Radcliffe Hospital, Oxford, UK
}

Correspondence to Zoe Elizabeth Barber, zbarber@doctors.net.uk

\section{DESCRIPTION}

Plombage, or extrapulmonary thoracoplasty, is the use of exogenous material to treat localised lung pathology. It was initially described by Tuffier as early as 1891. It was introduced in Britain in the late 1940s when the epidemic spread of tuberculosis combined with a lack of antituberculous drugs led to a vogue for surgical procedures to treat pulmonary tuberculosis before the advent of antituberculous drugs. ${ }^{1}$

A 77-year-old woman presented in April 2010 in acute respiratory distress (figure 1). She developed type II respiratory failure and rapidly deteriorated. In view of her impending respiratory arrest, she was intubated and taken to the intensive care unit where she was ventilated. She made an excellent recovery and was extubated 1 day later. A CT chest was performed, which showed significant extrinsic tracheal compression by the bilateral plombes (figure 2).

She was transferred to the care of the thoracic surgeons who performed rigid bronchoscopy, which confirmed significant tracheal compression of greater than $70 \%$ occlusion. A tracheal stent was placed with good clinical and bronchoscopic results.

She re-presented in extremis in September 2010 and again underwent rigid bronchoscopy. A second tracheal stent was placed with success. Unfortunately, she passed away later that year from an unrelated illness.

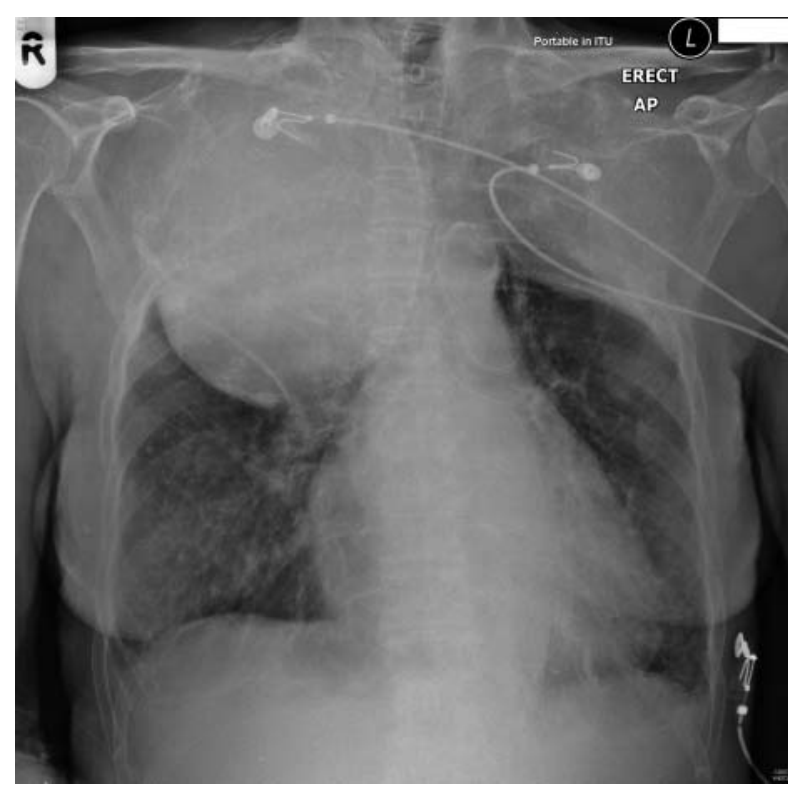

Figure1 Admission chest radiograph showing bilateral apical plombes.

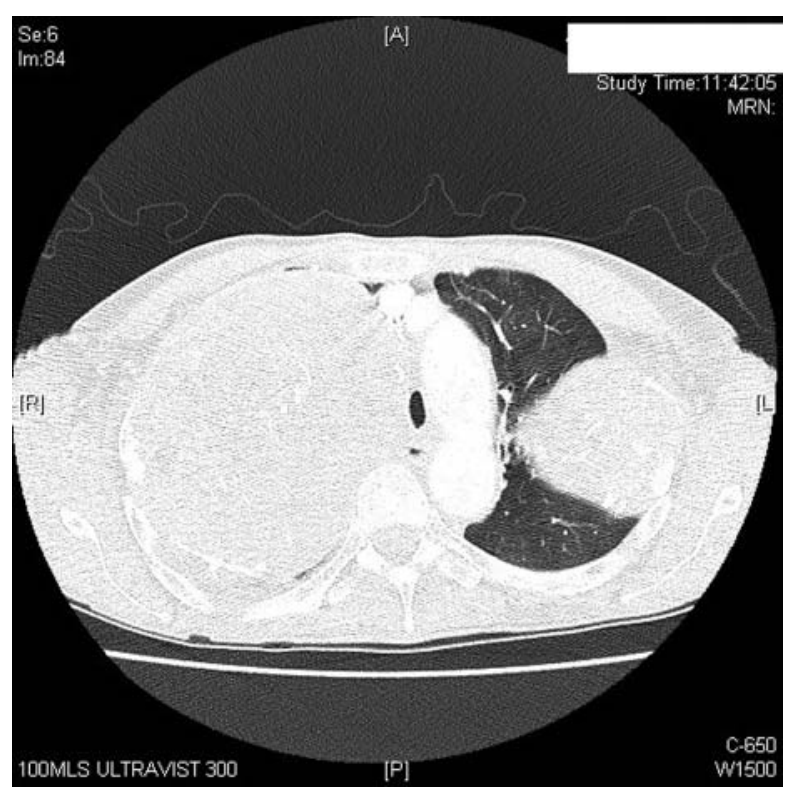

Figure 2 Chest CT demonstrating significant airway obstruction by bilateral plombes.

\section{Learning points}

- Plombage is a historical surgical technique which is not commonly seen today.

- Early complications were related to both the plombage material and the surgery itself. These include infection, foreign body rejection, extrusion or migration of the plombe and fistulation into other viscera. ${ }^{2}$

- Previously, argument was made for routine removal of plombes due to their early complication rate, but there are patients who have not undergone removal and are therefore at risk of late complications such as in this case.

Competing interests None.

Patient consent Obtained.

\section{REFERENCES}

1. Davies HM. The polyethylene pack operation for pulmonary tuberculosis. Thorax 1951;6:209-29.

2. Shields TW. Pulmonary tuberculosis and other mycobacterial infections of the lung. General Thoracic Surgery. 4th edn, 98. Philadelphia, USA: Lippincott Williams and Wilkins. 


\section{BMJ Case Reports}

This pdf has been created automatically from the final edited text and images.

Copyright 2012 BMJ Publishing Group. All rights reserved. For permission to reuse any of this content visit http://group.bmj.com/group/rights-licensing/permissions.

BMJ Case Report Fellows may re-use this article for personal use and teaching without any further permission.

Please cite this article as follows (you will need to access the article online to obtain the date of publication).

Barber ZE, Dobbs TD, Shahidi M. Tracheal compression: a late complication of plombage. BMJ Case Reports 2012;10.1136/bcr-2012-006367, Published XXX

Become a Fellow of BMJ Case Reports today and you can:

- Submit as many cases as you like

- Enjoy fast sympathetic peer review and rapid publication of accepted articles

- Access all the published articles

- Re-use any of the published material for personal use and teaching without further permission

For information on Institutional Fellowships contact consortiasales@bmjgroup.com

Visit casereports.bmj.com for more articles like this and to become a Fellow 